varying from $38 \%$ to $70 \%$. ${ }^{10}$ Surgeons fail to localise between a third and a half of non-metastatic gastrinomas intraoperatively, so techniques to enhance preoperative localisation are clearly needed. ${ }^{67}$ Transhepatic portal venous sampling has a sensitivity of only about $50 \%$ for microgastrinomas. This procedure can only regionalise, not localise, tumours and so the surgeon gains little useful information. ${ }^{11}$

Recently, selective arterial injection of secretin with angiography has been reported to localise $77-100 \%$ of gastrinomas, detecting tumours as small as $1 \mathrm{~mm} .{ }^{69}$ This new procedure relies on the exaggerated rise in gastrin concentration in the hepatic vein after injection of secretin into the artery supplying the tumour. Its advantages are high resolution and low morbidity as it is performed during conventional angiography. The local injection of secretin can show that angiographic abnormalities are functioning gastrinomas and can detect hepatic micrometastases when secretin is injected into the hepatic artery. Additionally, an intraoperative intravenous secretin test, using a rapid turnaround gastrin assay, can confirm that the tumour has been successfully cleared. ${ }^{6}$ Although experienced operators have reported similar localisation rates for endoscopic ultrasonography, ${ }^{1213}$ there are no reports that tumours smaller than $0.5 \mathrm{~cm}$ in diameter have been localised ultrasonographically, and the sensitivity falls the further the lesion is from the probe.

There is conflicting evidence concerning the impact of new imaging techniques on curative resection. Howard and colleagues report an improvement in cure rate from $27 \%$ to $87 \%$ in recent years, but the mean follow up of the recently operated group was only nine months. ${ }^{14}$ In contrast, Norton and colleagues found that the long term cure rate remains about $30 \%$ despite a disease free rate at three to six months' follow up of about $60 \% .^{15}$

Nearly a third of patients with a gastrinoma will have multiple endocrine neoplasia type 1 . The disease is usually multicentric, with tumours throughout the duodenum and pancreatic head, and an increased incidence of duodenal microgastrinomas. The tumours are apparently more benign than sporadic gastrinomas, although this may reflect earlier diagnosis. In patients with concurrent hyperparathyroidism the clinical and biochemical features of the gastrinoma syndrome are exacerbated, and parathyroidectomy should therefore be performed.

The subsequent surgical management of gastrinomas associated with multiple endocrine neoplasia type I is controversial. The multifocal nature of the disease, even without metastases, makes curative resection unlikely, and management is usually enucleation of gross, potentially metastatic lesions and control of symptoms with omeprazole. It has been suggested, however, that there is a subgroup of patients who have localised secretion of gastrin and thus may be cured. ${ }^{16}$ Selective arterial injection of secretin will allow identification of this subgroup.

P J HAMMOND MRC training fellow S R BLOOM

Department of Medicine, Professor of endocrinology

Hammersmith Hospital,

London W12 0HS

1 Hattori $Y$, Imamura $M$, Tobe $T$. Gastrin release from antral $G$ cells stimulated with secretin. Am $\mathcal{J}$ Gastroenterol 1992;87:195-200.

2 Chiba T, Yamatani T, Yamaguchi A, Morishita T, Nakamura A, Kadowaki S, et al. Mechanism for increase of gastrin release by secretin in Zollinger-Ellison syndrome. Gastroenterology 1989;96: 1439-44.

3 Feldman M, Schiller LR, Walsh JH, Fordtran JS, Richardson CT. Positive intravenous secretin test in patients with achlorhydria-related hypergastrinaemia. Gastroenterology 1987;93:59-62.

4 Stage JG, Stadil F, Rehfled JF, Kahrenkrug J, Schaffelitzky de Muckadell OB. Secretin and the Zollinger-Ellison syndrome: reliability of secretin tests and pathogenetic role of secretin. Scand $\mathcal{J}$ Gollinger-Ellison syndrome:

5 Primrose JN, Ratcliffe JG, Joffe SN. Differences between peptic ulcer and control patients on the basis of the response to secretin. Digestion 1985;32:249-54.

6 Imamura $M$, Kanda $M$, Takahashi K, Shimada Y, Miyahara T, Wagata T, et al. Clinicopathological characteristics of duodenal microgastrinomas. World f Surg 1992;16:703-10.

7 Thom AK, Norton JA, Axiotis CA, Jensen RT. Location, incidence, and malignant potential of duodenal gastrinomas. Surgery 1991;110:1086-91.

8 Frucht H, Doppman J, Norton JA, Miller DL, Dwyer AJ, Frank JA, et al. MR imaging of gastrinomas: comparison with computed tomography, angiography and ultrasound. Radiology 1989;171:713-8.

9 Doppman JL, Miller DL, Chang R, Maton PN, London JF, Gardner JD, et al. Gastrinomas: localisation by means of selective intra-arterial injection of secretin. Radiology 1990;174:25-9.

10 Maton PN, Miller DL, Doppman JL, Collen MJ, Norton JA, Vinayek R, et al. Role of selective angiography in the management of patients with Zollinger-Ellison syndrome. Gastroenterology 1987;92:913-8.

11 Vinik AI, Moattari AR, Cho K, Thompson N. Transhepatic portal vein catheterisation for localisation of sporadic and MEN gastrinomas: a ten-year experience. Surgery 1990;107:246-55.

Rosch T, Lightdale CJ, Botet JF, Boyce GA, Sivak MV Jr, Yasuda K, et al. Localisation of pancreatic endocrine tumours by endoscopic ultrasonography. N Engl f Med 1992;326:1721-6.

13 Palazzo L, Roseau G, Salmeron M. Endoscopic ultrasonography in the preoperative localisation of pancreatic endocrine tumours. Endoscopy 1992;24:350-3.

14 Howard TJ, Zinner MJ, Stabile BE, Passaro E Jr. Gastrinoma excision for cure. A prospective analysis. Ann Surg 1990;211:9-14.

15 Norton JA, Doppman JL, Jensen RT. Curative resection in Zollinger-Ellison syndrome. Results of a 10-year prospective study. Ann Surg 1992;215:8-18.

6 Thompson NW, Bondeson AG, Bondeson L, Vinik A. The surgical treatment of gastrinoma in MEN 1 syndrome patients. Surgery 1989;106:1081-5.

\title{
Reviewing the NHS review
}

\section{More substantial changes on the way}

The future direction of the NHS reforms is currently under scrutiny by a review team established by Virginia Bottomley. The decision to appoint the team was announced in February at a conference on managing the market. At that time it was seen primarily as a way of resolving the future of the intermediate tier of NHS management-the term used to describe the 14 regional health authorities and six outposts of the management executive.

In the event, much wider terms of reference have been established.' These centre on an analysis of what needs to be done to ensure that the NHS reforms are fully effected. General practice fundholders and NHS trusts have an assured future, but all other aspects of the structure of the NHS are being scrutinised. What was originally perceived as a technical exercise of interest mainly to NHS insiders has thus become a fundamental examination of the reforms as a whole.

The reasons for this are not hard to find. The most important is the involvement of the prime minister's office, spurred on by a concern within the government to ensure that Mrs Bottomley remains faithful to the original purpose of the reforms. At one level this is manifested in the desire to ensure that NHS trusts are not enmeshed in unnecessary bureaucratic controls at the intermediate tier. More fundamentally, it stems from a policy of cutting back on inappropriate central and regional controls to enable the market to come into play more fully. At the same time the review provides an opportunity to tidy up some of the loose ends that have emerged, such as the overlapping responsibilities of district health authorities and family health services authorities and the relation between these authorities and general practice fundholders.

The membership of the review team gives some clues as to the likely outcome of its work. Of particular significance is the appointment of Kate Jenkins to lead the review. Ms Jenkins is 
a former civil servant who now works as an independent management consultant and sits on the NHS Policy Board. She is best known for her work on the "next steps" report," prepared during a spell in the No 10 Efficiency Unit during Mrs Thatcher's period in office. This report started the process of hiving off agencies from the government and has had a more important effect on Whitehall than any other single change during this century.

Equally important is the involvement of Peter Griffiths, recently displaced as chief executive of Guy's and Lewisham NHS Trust. A career NHS manager, Griffiths has been one of the most enthusiastic advocates of the reforms. He is a strong supporter of freedom for the NHS trusts and a critic of bureaucracy.

For a review that is due to be completed by July it was remarkable that its terms of reference were not published until May. This suggests that the Department of Health and 10 Downing Street did not see eye to eye on the scope of the exercise. In this context it is particularly significant that the review team has been asked to focus on what needs to be done to ensure that the proportion of NHS expenditure devoted to direct patient care is maximised. A key target is certain to be management costs, especially the arrangements that exist above the level of local purchasers and providers.

Around 12000 staff are currently employed at this level in regional health authorities, the NHS Management Executive, and the Department of Health. Each regional health authority has already been told to reduce its staff to a maximum of 200 , and further cuts are certain to follow. The review will include an assessment of what functions and staffing are needed in the management executive to bring "head office" into line with the changes that have taken place locally. The management executive employs over 1000 staff at a cost of around $£ 35 \mathrm{~m}$, and the added value of these staff is under careful examination. The same applies to the rest of the Department of Health.

Another issue being studied is the arrangements needed at the local level to ensure that the reforms really do work for patients. There is a widely held view in the NHS that legislation to enable district health authorities and family health services authorities to merge is desirable. This view recently received authoritative endorsement from the Audit Commission. ${ }^{3}$ The creation of unified purchasing agencies would not only reduce unnecessary bureaucracy within the NHS, but also make it easier to plan primary and secondary care services on a common basis. Provided that general practice fundholders can be made properly accountable to these agencies for delivering strategic objectives, there is an opportunity to establish a coherent purchasing function able to drive the reforms forward. The experience of a third member of the review team, Ian Carruthers, who is chief executive of Dorset Health Commission, an agency which brings together the district health authority and the family health services authority, will be especially important in this.

The review also makes it possible to clarify the arrangements needed at the intermediate tier. The current division of responsibilities, with regional health authorities managing the affairs of purchasers and outposts of the management executive monitoring NHS trusts, makes no sense at all. The intermediate tier's most important function is regulation or market management. ${ }^{4}$ This is best discharged by a single agency that can take a strategic oversight of the market's operation. The review team should concentrate on spelling out the nature of market management and avoid becoming embroiled in the question of whether regional health authorities or outposts of the management executive should survive. The reality is that an entirely new agency is needed at this level, quite different from the bodies that currently exist.

The future of the intermediate tier cannot be separated from the issue of what kind of market ministers wish to see develop. The emphasis so far has been placed on gradual change and managed competition. While some people have argued that it is now time to relax the controls that have been put in place, going too far in this direction would be risky. Priority should be given to introducing a greater degree of contestability into the provision of services rather than promoting a competitive tendering approach. Only in this way will a properly regulated market emerge.

The question remains of how accountability can best be ensured. As recent events in West Midlands and Wessex have shown, the policy pursued during the 1980s of making the NHS more businesslike and entrepreneurial has had some unfortunate consequences. In the biggest organisation in western Europe detailed supervision of local managers by those at the centre will always be difficult, yet that is precisely what parliamentary accountability demands.

One way of resolving this dilemma would be to establish the NHS as a Next Steps agency. This would have the effect of creating an arm's length relationship between the secretary of state and the NHS, in which ministers concentrated on setting strategic goals and targets and avoided involvement in detailed matters of operational management. Although this option has some attractions, it is unlikely to be acceptable to members of parliament, who expect to be able to question ministers on the minutiae of what remains a highly visible and valued public service. The most that can be expected, therefore, is that ministers will impose a self denying ordinance and concentrate on major issues of policy and direction. The accountability of health authorities would then be ensured through an effective performance management function. As part of this the goals set out in corporate contracts between different tiers of management would provide the focus for assessing how national policies are implemented.

The other key aspect of accountability concerns the issue of corporate governance within the NHS. There is now mounting evidence that the non-executive members of health authorities and trusts are not always fully aware of their responsibilities and have sometimes failed to discharge their duties effectively. This includes not holding managers and executive chairs accountable. The review team has specifically been asked to examine the conclusions of the Cadbury report on corporate governance, which has recently made proposals for strengthening the role of boards in the private sector. ${ }^{5}$ It would not be surprising if the review recommended the use of an audit committee of non-executives, the appointment of a manager to act as company secretary, and the development of a programme of training and development to help non-executives to perform their duties.

All of this amounts to a huge agenda. How much progress is possible by this month's deadline is uncertain, but what is not in doubt is that a further programme of substantial change is in prospect. At a time when Michael Portillo's fundamental economic review is asking some uncomfortable questions about public spending, it is safe to predict that cutting back on the costs of management will be a high priority. If the review of functions and manpower can also be used to tackle some of the problems of particular concern within the NHS, such as the future configuration of purchasing, it will indeed have served a useful purpose.

Health Services Management Centre,

CHRIS HAM Director

University of Birmingham, Birmingham B15 2RT

\footnotetext{
Department of Health. Functions and manpower review terms of reference announced. London: DoH, 1993. (Press release.)

2 Efficiency Unit. Improving management in government: the next step. London: HMSO, 1988.

3 Audit Commission. Their health, your business: the new role of the district health authority. London: HMSO, 1993.

4 Ham C. What future for the regions? BMF 1993;305:130-1.

5 Cadbury Committee. Financial aspects of corporate governance. London: Gee and Co, 1992
} 